\title{
Studies on the Physiological Characteristics of (Cervus e. canadensis) Velvet Antler in Elk
}

\author{
Byong Tae Jeon ${ }^{1}$, David G Thomas ${ }^{2}$, Sun Hee Cheong ${ }^{1}$, Myeong Hwa Kim${ }^{1}$, Sung Jin Kim ${ }^{1}$, Si Heung Sung ${ }^{1}$, \\ Pyo Jam Park ${ }^{1}$, Jae Hyun Park ${ }^{1}$ and Sang Ho Moon ${ }^{1} *$ \\ ${ }^{1}$ Korea Nokyong Research Center, Konkuk University, Chungju, 380-701, Korea \\ ${ }^{2}$ Institute of Food, Nutrition and Human Health, Massey University, Palmerston North, New Zealand
}

\begin{abstract}
In order to investigate the physiological properties of velvet antler of elk (Cervus e. canadensis) raised in Korea, antlers $(n=378)$ were collected from deer in 8 provinces including Gyeonggi-do $(n=53)$, Gangwon-do $(n=49)$, Chungcheongbuk-do ( $n=62)$, Chungcheongnam-do ( $n=68)$, Jeollabuk-do $(n=52)$, Jeollanam-do $(n=15)$, Gyeongsangbuk-do $(n=30)$ and Gyeongsangnam-do $(n=49)$. The exterior characteristics (weight, length, girth and crown) of all antlers were measured, and 18 antler samples were randomly selected for measurement of interior characteristics such as specific gravity, capacity and diameter of cross section. The mean antler weight, length of the main beam and mean length of upper section were $4.87 \pm 1.79 \mathrm{~kg}, 83.7 \pm 13.2 \mathrm{~cm}$ and $40.6 \pm 11.4 \mathrm{~cm}$, respectively. Mean girth of the top, middle and base of the main beam were $27.1 \pm 5.9 \mathrm{~cm}, 22.1 \pm 3.6 \mathrm{~cm}$ and $22.9 \pm 3.6 \mathrm{~cm}$ respectively, indicating a slight narrowing in the middle of the antler. In each of the tines, the girth at the base was markedly thicker compared to the top. The depth of the crown at the top of the antler, and the average number of crowns and tines were $14.1 \pm 7.0 \mathrm{~cm}, 2.1 \pm 0.6$ and 3.0 \pm 0.5 , respectively. Although there was no significant difference in mean specific gravity between top and base, mean specific gravity of main beam tended to increase from top to base of the antler with decreasing capacity. Additionally, the inner diameter of the base of the antler was significantly reduced compared to that of the top, indicating a greater integumental thickening due to mineralization. Information on the morphological and physiological properties of elk antlers is scarce. Therefore, these results may be useful in providing basic information for the physiological properties of antler, and encourage further studies on antler morphology in other deer species showing species specific differences.
\end{abstract}

(Key words : Elk, Physiological Properties, Velvet Antler)

\section{INTRODUCTION}

Velvet antler has been an important traditional oriental medicine for hundreds of years. More recently, deer farming which is an alternative form of animal agriculture in many parts of the world, has grown rapidly in response to an increasing demand for velvet antler (Sim, 1987). Antlers are bony protuberances that form on the heads of animals from the family Cervidae (deer) which have been in recorded existence for over 25 million years (Chapman, 1975). Elk, red deer, and sika deer are three examples of the 40 species of deer that have antlers, and additionally there are four species that are antlerless (Chapman, 1975). Antlers are one of the fastest growing tissues in the animal kingdom, growing by as much as $14 \mathrm{~kg}$ in 6 months, with a peak growth rate of 2 4 $\mathrm{cm}$ day $^{-1}$ (Modell, 1969; Wolfe, 1982). Antlers are male cephalic appendages that cast and regenerate each year from the apices of pedicles. Pedicles are permanent protuberances that start to develop from the lateral crests of deer frontal bone during puberty (Fennessy and Suttie, 1985; Kierdorf et al., 1993; Ian et al., 2000). The first antlers are generated spontaneously after pedicles grow to a species-specific height (50 60 mm high in red deer) ( $\mathrm{Li}$ and Suttie, 2000). Pedicles and growing antlers are made up of exterior and interior components. The exterior component consists of a velvet-like skin and pedicle skin which is typical of deer scalp skin, while the interior component is composed of osseo-cartilaginous tissue (Li and Suttie, 1994).

Commercially, the length of the velvet antler is frequently used as a quality index. Antler length has been shown to be influenced by environmental conditions, genetics, age, birth weight, body weight, nutrition, cutting time and deer density (Moore et al., 1988; Ball et al., 1994; Ian et al., 2000; Fierro et al., 2002). Recent studies have demonstrated that

* Corresponding author: Dr. S. H. Moon, Department of Animal Science, College of Natural Sciences, Konkuk University, Chungju, 380-701, Korea. Tel: +82-43-840-3527, Fax: +82-43-851-8216, E-mail: moon0204@kku.ac.kr 
individual differences in body weight at weaning remain fixed until 1.5 years of age (Landete-Castillejos et al., 2001). It has been reported that fodder diversity and nutritional status of deer have an effect on the length, girth and tine number of the velvet antler (Ullrey, 1983; Schmidt et al., 2001). Studies have also shown that the chemical composition of the antler varies with both the region of the antler, and with antler size and weight (Turner and Burr, 1993). A number of recent studies have linked velvet antler consumption with an enhanced sense of well being and vitality, improved musculoskeletal function, enhanced resistance to disease and immune system modulation, increased blood flow and blood pressure modulation, and promotion of rapid healing in tissues and bones (Elliott et al., 1996; Hemmings and Song, 2004; Moreau et al., 2004). Although some studies on the chemical components and bioavailability of entire velvet antler have been carried out, there has been little research activity on standardization of farmed velvet antler, in particular, the physical dimensions and physiological properties of different areas of the antler.

In this study, we report on the physiological properties of velvet antler from elk(Cervus e. canadensis) farmed in Korea. This is the first comprehensive report on antlers from this species of deer, providing both exterior production characteristics such as length, girth and crown, and interior characteristics such as specific gravity, capacity and diameter of cross section of antler.

\section{MATERIALS AND METHODS}

\section{Animals}

This study was carried out in randomly-selected deer farms in Korea, from June to August 2006. Velvet antlers ( $n=378$ ) from elk(Cervus e. canadensis) were collected in 8 provinces including Gyeonggi-do $(n=53)$, Gangwon-do $(n=49)$, Chungcheongbuk-do ( $n=62)$, Chungcheongnam-do ( $n=68)$, Jeollabukdo ( $n=52)$, Jeollanam-do $(n=15)$, Gyeongsangbuk-do $(n=30)$, and Gyeongsangnam-do $(n=49)$ in Korea. All deer sampled were healthy, with no clinical signs of disease.

\section{Sampling procedure}

Antlers that were harvested from 80 to 90 days after casting were collected from deer farms in each province. Samples of antler were taken, rapidly washed in water, placed into cryovials, weighed and immediately stored at $-40^{\circ} \mathrm{C}$ until analysis.

\section{Measurement}

The main beam of each collected antler was divided into 5 sections (top, upper, middle, base, and bottom) and each tine was measured separately. Samples of each section were sliced with bone slicer. The exterior characteristics of each antler were measured (weight, length, girth and crown). Weight of antler was measured to the nearest $0.05 \mathrm{~kg}$ using electronic scale. The inside length of the main beam was measured from the burr to the tip. Burr and pedicle circumference were also measured. The width and depth of each sample were recorded to the nearest $0.1 \mathrm{~cm}$ using a digital caliper prior to testing. Samples $(n=18)$ were then randomly selected for measurement of interior characteristics such as specific gravity, capacity and diameter of cross section. Volume was determined from the difference in weight of the antlers in air and in water; the weight under water of the more porous antlers had to be recorded rapidly to prevent water displacing air from the internal spaces. The dry weight of the antlers was determined subsequently after drying for $48 \mathrm{~h}$ at $105^{\circ} \mathrm{C}$. The specific gravity (g dry matter/ $\mathrm{ml}$ ) of the antler was estimated from the weight and volume measurements described previously. All measures were carried out using a measuring tape. The different exterior and interior measurements taken are shown in Fig. 1.

\section{Statistical analysis}

All data are presented as mean and standard deviation. Analysis of variance with Duncan's multiple range test was performed to evaluate differences between the groups. The Statistical Analysis System version 8.01 was used for all analyses (SAS Institute, Cary, NC, U.S.A). Statistical significance was defined as $\mathrm{p}<0.05$.

\section{RESULTS AND DISCUSSION}

\section{The antler weight and length in elk}

Table 1 shows the mean weight and length of the main beam and tines of velvet antler of elk farmed in Korea. The mean weight of antler was $4.87 \pm 1.79 \mathrm{~kg}$. Antler weight was significantly affected by region as shown in Table $1(\mathrm{p}<$ 


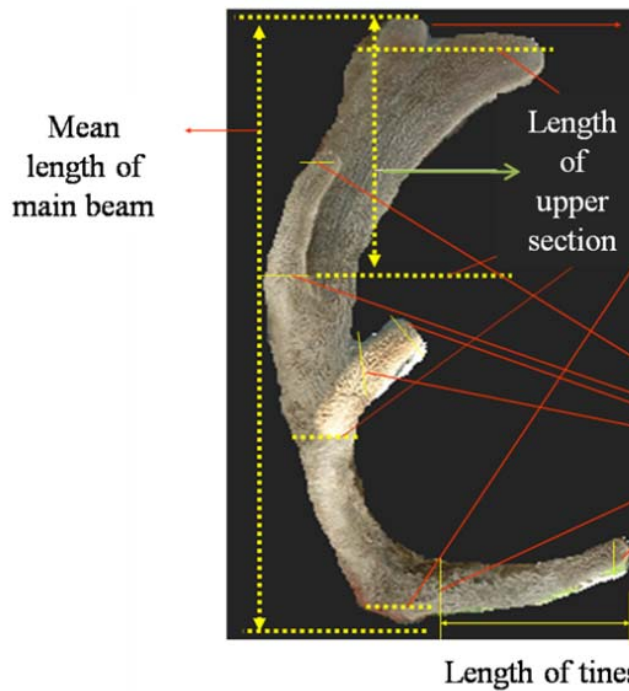

Depth of the crown

Girth of main beam (upper, middle, base)

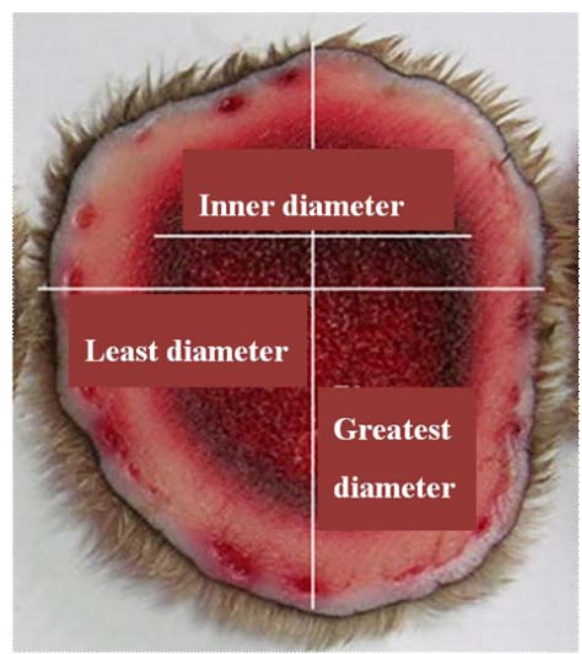

Fig. 1. Measurements of Exterior and Interior Elements of Antler in Elk (Cervus e. canadensis).

Table 1. Production and Length of Different Sections of Antler in Elk (Cervus e. canadensis)

\begin{tabular}{|c|c|c|c|c|c|c|c|}
\hline & \multirow{2}{*}{$\begin{array}{c}\text { Mean weight } \\
\text { of antler } \\
\text { (kg) }\end{array}$} & \multirow{2}{*}{$\begin{array}{l}\text { Mean length } \\
\text { of main beam } \\
(\mathrm{cm})\end{array}$} & \multirow{2}{*}{$\begin{array}{l}\text { Mean length } \\
\text { of the upper } \\
\text { section }(\mathrm{cm})\end{array}$} & \multicolumn{4}{|c|}{ Length of the tines $(\mathrm{cm})$} \\
\hline & & & & First & Second & Third & Fourth \\
\hline Gyeonggi-do $(n=53)$ & $4.83 \pm 1.78^{\mathrm{bc}}$ & $85.0 \pm 15.0^{\mathrm{bc}}$ & $42.2 \pm 15.3^{\text {cde }}$ & $41.1 \pm 12.4^{\mathrm{a}}$ & $35.9 \pm 12.8^{\mathrm{ab}}$ & $30.6 \pm 10.9^{\mathrm{abc}}$ & - \\
\hline Gangwon-do $(n=49)$ & $5.19 \pm 2.09^{\mathrm{bcd}}$ & $88.1 \pm 15.2^{\mathrm{bc}}$ & $42.2 \pm 8.5^{\text {cde }}$ & $40.8 \pm 9.5^{\mathrm{a}}$ & $33.1 \pm 9.7^{\mathrm{a}}$ & $30.3 \pm 8.4^{\mathrm{abc}}$ & $34.3 \pm 6.5^{\mathrm{bc}}$ \\
\hline Chungcheongbuk-do ( $n=62)$ & $3.93 \pm 1.28^{\mathrm{a}}$ & $75.6 \pm 11.9^{\mathrm{a}}$ & $35.0 \pm 9.9^{\mathrm{a}}$ & $39.0 \pm 9.2^{\mathrm{a}}$ & $32.1 \pm 9.2^{\mathrm{a}}$ & $26.7 \pm 6.4^{\mathrm{a}}$ & - \\
\hline Chungcheongnam-do $(n=68)$ & $4.53 \pm 1.64^{\mathrm{ab}}$ & $84.5 \pm 10.7^{\mathrm{bc}}$ & $40.4 \pm 9.2^{\mathrm{bcd}}$ & $44.1 \pm 11.7^{\mathrm{ab}}$ & $33.7 \pm 12.4^{\mathrm{a}}$ & $28.0 \pm 7.4^{\mathrm{ab}}$ & $31.3 \pm 9.8^{b}$ \\
\hline Jeollabuk-do $(n=52)$ & $5.26 \pm 2.12^{\mathrm{bcd}}$ & $81.8 \pm 15.3^{b}$ & $46.9 \pm 9.8^{\mathrm{e}}$ & $38.9 \pm 9.5^{\mathrm{a}}$ & $34.3 \pm 10.5^{\mathrm{a}}$ & $33.1 \pm 9.5^{\mathrm{c}}$ & $38.1 \pm 4.9^{c}$ \\
\hline Jeollanam-do $(n=15)$ & $5.45 \pm 1.56^{\mathrm{cd}}$ & $84.1 \pm 9.3^{\mathrm{bc}}$ & $36.4 \pm 9.2^{\mathrm{ab}}$ & $49.1 \pm 7.0^{b}$ & $39.8 \pm 10.4^{\mathrm{b}}$ & $31.7 \pm 11.6^{\mathrm{bc}}$ & $26.8 \pm 4.5^{\mathrm{a}}$ \\
\hline Gyeongsangbuk-do $(n=30)$ & $6.02 \pm 1.62^{\mathrm{d}}$ & $89.5 \pm 9.7^{c}$ & $44.1 \pm 10.9^{\mathrm{de}}$ & $47.2 \pm 10.4^{\mathrm{b}}$ & $39.9 \pm 12.2^{\mathrm{b}}$ & $29.0 \pm 8.7^{\mathrm{abc}}$ & $24.6 \pm 9.1^{\mathrm{a}}$ \\
\hline Gyeongsangnam-do $(n=49)$ & $4.96 \pm 1.32^{\mathrm{bc}}$ & $86.0 \pm 7.9^{\mathrm{bc}}$ & $37.2 \pm 11.7^{\mathrm{abc}}$ & $41.9 \pm 9.9^{\mathrm{a}}$ & $37.2 \pm 11.0^{\mathrm{ab}}$ & $27.5 \pm 5.9^{\mathrm{ab}}$ & - \\
\hline Average & $4.87 \pm 1.79$ & $83.7 \pm 13.2$ & $40.6 \pm 11.4$ & $41.9 \pm 10.6$ & $34.9 \pm 11.3$ & $29.4 \pm 8.7$ & $31.8 \pm 8.3$ \\
\hline
\end{tabular}

Values are means with their $\mathrm{SD}(n=378)$.

abcde Means in each column with different superscripts differ $(\mathrm{p}<0.05)$.

0.05). Antler weight was significantly higher in Gyeongsangbukdo $(6.02 \pm 1.62 \mathrm{~kg})$ compared to Chungcheongbuk-do (3.93 \pm $1.28 \mathrm{~kg} ; \mathrm{p}<0.05)$. Previous studies by our group have demonstrated that antler weight, mean length of main beam and girth at the base of the main beam are all affected by dietary protein level (Jeon et al., 2005). Moreover, other studies suggested that antler weight accounts for $1 \sim 5 \%$ of body weight and antler production is positively correlated with body weight (Ball et al., 1994; Ian et al., 2000). Mean length of the main beam was $83.7 \pm 13.2 \mathrm{~cm}$, and a similar regional pattern was observed in main beam length to that previously observed for antler weight. The length of the main beam was significantly longer in Gyeongsangbuk-do $(89.5 \pm 9.7 \mathrm{~cm})$, compared to Chungcheongbuk-do $(75.6 \pm 11.9$ $\mathrm{cm} ; \mathrm{p}<0.05)$. Mean length of the upper section was $40.6 \pm$ $11.4 \mathrm{~cm}$, and the length of upper section in Jeollabuk-do 
$(46.9 \pm 9.8 \mathrm{~cm})$ was significantly longer than in Chungcheongbukdo $(35.0 \pm 9.9 \mathrm{~cm} ; \mathrm{p}<0.05)$. Several previous studies have suggested that antler length is affected by environmental conditions, region, nutrition and dietary protein level (Muir and Sykes, 1988; Jeon et al., 2005). The length of the first tine was significantly longer than that of the third tine (41.9 $\pm 10.6 \mathrm{~cm}$ for first tine vs. $34.9 \pm 11.3 \mathrm{~cm}$ for second tine vs. $29.4 \pm 8.7 \mathrm{~cm}$ for third tine; $\mathrm{p}<0.05$ ). The length of first and second tines was significantly longer in Jeollanam-do and Gyeongsangbuk-do than in all other areas $(\mathrm{p}<0.05)$. However, the length of third tine was longest in Jeollabukdo $(33.1 \pm 9.5 \mathrm{~cm} ; \mathrm{p}<0.05)$ and shortest in Chungcheongbukdo $(26.7 \pm 6.4 \mathrm{~cm} ; \mathrm{p}<0.05)$. Moreover, the mean weight of antler was positively correlated with the mean length of main beam and upper section. Several studies have demonstrated that body weights at the end of the first antler growth period are positively correlated with final antler length (Moore et al., 1988; Gaspar-López et al., 2008). Also, Gómez et al. (2006) described a positive correlation between weight at weaning and some characters of antler quality, such as length and basal perimeter. Therefore, it appears advantageous to ensure that maximal body weight is achieved by the end of the first antler growth period to improve subsequent antler production.

\section{Girth of velvet antler in elk}

Table 2 shows the mean girth of the top, middle and base of the main beam and the top and base of each tine on the antler in elk. The mean girth of the main beam was $27.1 \pm$ $5.9 \mathrm{~cm}$ at the top, $22.1 \pm 3.6 \mathrm{~cm}$ in the middle, and $22.9 \pm$ $3.6 \mathrm{~cm}$ at the base, which indicated a narrowing of the main beam from top to bottom. The girth of the antler was again significantly affected by region, and a similar pattern was observed to the previous antler weight and length of main beam results. Ungerfeld et al. (2008) reported that the girth of an antler was positively correlated with velvet antler production. Separately, Kruuk et al. (2002) reported that both antler size and girth are heavily dependent on an individual animal's nutritional state. Although several studies described the relationship between antler production and environmental factors such as nutritional status, heritability, and body weight, no research has been carried out looking at the physiological properties of antlers across different farming regions.

In the present study, the girth at the top of the main beam was largest in Gyeonggi-do $(29.0 \pm 5.9 \mathrm{~cm})$ and smallest in Jeollabuk-do $(25.2 \pm 6.4 \mathrm{~cm} ; \mathrm{p}<0.05)$. The girth at the middle of the main beam was largest in Gyeongsangbuk-do

Table 2. Girth of Different Sections of Antler in Elk (Cervus e. canadensis)

\begin{tabular}{|c|c|c|c|c|c|c|c|c|c|c|c|}
\hline & & & $\begin{array}{c}\text { Gyeonggi- } \\
\text { do } \\
(n=53)\end{array}$ & $\begin{array}{c}\text { Gangwon- } \\
\text { do } \\
(n=49)\end{array}$ & $\begin{array}{c}\text { Chungcheons } \\
\text { buk-do } \\
(n=62)\end{array}$ & $\begin{array}{c}\text { Chungcheong } \\
\text { nam-do } \\
(n=68)\end{array}$ & $\begin{array}{c}\text { Jeollabuk- } \\
\text { do } \\
(n=52)\end{array}$ & $\begin{array}{c}\text { Jeollanam- } \\
\text { do } \\
(n=15)\end{array}$ & $\begin{array}{c}\text { Gyeongsang } \\
\text { buk-do } \\
(n=30)\end{array}$ & $\begin{array}{c}\text { Gyeongsang } \\
\text { nam-do } \\
(n=49)\end{array}$ & Average \\
\hline \multirow{3}{*}{$\begin{array}{l}\text { Mean girth } \\
\text { of main } \\
\text { beam }(\mathrm{cm})\end{array}$} & Top & & $29.0 \pm 5.9^{c}$ & $27.0 \pm 4.5^{\mathrm{abc}}$ & $25.5 \pm 5.6^{\mathrm{ab}}$ & $27.5 \pm 6.4^{\mathrm{abc}}$ & $25.2 \pm 6.4^{\mathrm{a}}$ & $26.9 \pm 4.0^{\mathrm{abc}}$ & $28.3 \pm 5.2^{\mathrm{bc}}$ & $27.9 \pm 6.1^{\mathrm{abc}}$ & $27.1 \pm 5.9$ \\
\hline & Middle & & $20.5 \pm 3.0^{\mathrm{a}}$ & $23.0 \pm 4.1^{\mathrm{cd}}$ & $21.1 \pm 3.0^{\mathrm{ab}}$ & $22.3 \pm 3.8^{b c}$ & $21.2 \pm 3.4^{\mathrm{ab}}$ & $22.4 \pm 2.2^{\mathrm{bc}}$ & $24.1 \pm 3.6^{\mathrm{d}}$ & $23.7 \pm 3.8^{\mathrm{cd}}$ & $22.1 \pm 3.6$ \\
\hline & Base & & $23.0 \pm 3.9^{\mathrm{a}}$ & $23.5 \pm 3.9^{\mathrm{ab}}$ & $22.0 \pm 3.0^{\mathrm{ab}}$ & $22.1 \pm 3.2^{\mathrm{a}}$ & $22.7 \pm 2.9^{\mathrm{a}}$ & $23.6 \pm 4.2^{\mathrm{ab}}$ & $25.1 \pm 4.1^{\mathrm{b}}$ & $22.8 \pm 3.6^{\mathrm{a}}$ & $22.9 \pm 3.6$ \\
\hline \multirow{8}{*}{$\begin{array}{l}\text { Mean girth } \\
\text { of tines }(\mathrm{cm})\end{array}$} & \multirow{2}{*}{ First } & Top & $9.3 \pm 1.8^{\mathrm{ab}}$ & $8.9 \pm 1.8^{\mathrm{a}}$ & $9.5 \pm 2.3^{\mathrm{ab}}$ & $9.2 \pm$ & $9.3 \pm 1.2^{\mathrm{ab}}$ & $10.0 \pm 1.4^{\mathrm{b}}$ & $11.1 \pm 2.9^{c}$ & $9.1 \pm 2.4^{\mathrm{ab}}$ & $9.4 \pm 2.2$ \\
\hline & & Base & $14.9 \pm 1.7^{\mathrm{a}}$ & $15.3 \pm 2.4^{\mathrm{ab}}$ & $14.5 \pm 1.9^{\mathrm{a}}$ & $15.3 \pm 1.8^{\mathrm{ab}}$ & $15.0 \pm 2.0^{\mathrm{a}}$ & $17.1 \pm 2.7^{c}$ & $16.2 \pm 2.7^{\mathrm{bc}}$ & $14.9 \pm 3.1^{\mathrm{a}}$ & $15.2 \pm 2.3$ \\
\hline & \multirow{2}{*}{ Second } & Tc & $9.3 \pm 1.2^{\mathrm{b}}$ & $8.8 \pm 1.6^{\mathrm{ab}}$ & $8.9 \pm 1.7^{\mathrm{ab}}$ & $8.5 \pm 1.5^{\mathrm{a}}$ & $8.7 \pm 1.2^{\mathrm{ab}}$ & $9.0 \pm 1.4^{\mathrm{ab}}$ & $9.3 \pm 1.4^{\mathrm{b}}$ & $9.2 \pm 1.0^{\mathrm{ab}}$ & $8.9 \pm 1.4$ \\
\hline & & Base & $14.5 \pm 2.1^{\mathrm{abc}}$ & $14.2 \pm 2.4^{\mathrm{ab}}$ & $13.7 \pm 1.8^{\mathrm{a}}$ & $14.4 \pm 2.2^{\mathrm{abc}}$ & $13.6 \pm 1.9^{\mathrm{a}}$ & $15.1 \pm 1.7^{\mathrm{bc}}$ & $15.3 \pm 2.5^{\mathrm{c}}$ & $15.1 \pm 2.4^{\mathrm{bc}}$ & $14.3 \pm 2.2$ \\
\hline & \multirow{2}{*}{ Third } & Top & $10.5 \pm 2.1^{\mathrm{a}}$ & $9.5 \pm 2.3^{\mathrm{a}}$ & $10.7 \pm 2.8^{\mathrm{a}}$ & $9.5 \pm 2.0^{\mathrm{a}}$ & $10.5 \pm 2.8^{\mathrm{a}}$ & $12.4 \pm 4.3^{\mathrm{b}}$ & $9.9 \pm 1.7^{\mathrm{a}}$ & $10.2 \pm 1.6^{\mathrm{a}}$ & $10.2 \pm 2.5$ \\
\hline & & Base & $15.7 \pm 2.6^{\mathrm{NS}}$ & $16.7 \pm 3.3$ & $15.6 \pm 2.4$ & $16.1 \pm 2.6$ & $15.6 \pm 2.3$ & $16.3 \pm 2.4$ & $15.8 \pm 2.4$ & $16.6 \pm 2.4$ & $16.0 \pm 2.6$ \\
\hline & \multirow{2}{*}{ Fourth } & Top & - & $12.0 \pm 2.4$ & - & $11.0 \pm 0.7$ & $14.7 \pm 4.5$ & $12.7 \pm 2.3$ & $14.0 \pm 1.6$ & - & $12.9 \pm 2.9$ \\
\hline & & Base & - & $20.0 \pm 2.8$ & - & $25.6 \pm 9.0$ & $19.6 \pm 3.8$ & $17.5 \pm 2.3$ & $17.3 \pm 2.1$ & - & $19.7 \pm 4.5$ \\
\hline
\end{tabular}

Values are means with their SD $(n=378)$.

abcd Means in each row with different superscripts differ $(p<0.05)$.

N.S.: Not significant. 
$(24.1 \pm 3.6 \mathrm{~cm})$ and smallest in Gyeonggi-do $(20.5 \pm 3.0 \mathrm{~cm}$; $\mathrm{p}<0.05)$. Similarly, the girth at the base of the main beam was significantly biggest in Gyeongsangbuk-do (25.1 \pm 4.1 $\mathrm{cm})$ and smallest in Chungcheongbuk-do $(22.0 \pm 3.0 \mathrm{~cm} ; \mathrm{p}<$ $0.05)$. In the present study, the mean girth of the main beam was strongly related to antler production. The girth of the top portion of the main beam which includes the first, second, and third tines, was significantly thicker than that at the base of the main beam $(\mathrm{p}<0.05)$.

\section{Exterior characteristics of crown of antler in elk}

Exterior characteristics of the crown of the antler in elk are shown in Table 3. In the present study, the mean number of crowns was 2.1. The number of crowns tended to be higher in Gangwon-do and Gyeongsangbuk-do, compared to Chungcheongbuk-do. The mean depth of the crown was $14.1 \pm 7.0 \mathrm{~cm}$, with the depth of crown deepest in Gyeonggido $(16.5 \pm 7.0 \mathrm{~cm})$ and shallowest in Jeollabuk-do $(11.6 \pm 6.8$ cm; p<0.05). Landete-Castillejos et al. (2007) reported that the cortical bone depth of antler was affected by the mineral or food availability. The mean girth of the crown was 17.2 $\pm 5.5 \mathrm{~cm}$, with the girth of the crown largest in Jeollanamdo $(19.0 \pm 3.0 \mathrm{~cm})$ and smallest in Chungcheongbuk-do (16.1 $\pm 3.6 \mathrm{~cm}$; $\mathrm{p}<0.05$ ). The mean number of tines on each antler was 3.0. The number of tines was highest in Jeollanam-do (3.2) and lowest in Gyeonggi-do and Gyeongsangnam-do (2.8; $\mathrm{p}<0.05)$. These results suggest that strong differentiation of exterior characteristics occurs in antlers of elk in different regions of Korea.
4. Weight, specific gravity, capacity, diameter of cross section of antler in elk

In the next stage of the study, we compared the exterior and interior characteristics of elk antler. For this purpose, we randomly selected 18 antler samples for measurement of interior characteristics such as specific gravity, capacity and diameter of cross section (Table 4). Each antler was cut into 5 sections (top, upper, middle, base, and bottom) of main beam and the 3 tines were removed. The mean weight of each section of antler and its percentage of total antler weight (\%) tended to be highest in top and bottom sections and lowest in the middle sections (top: $769.8 \pm 278.5 \mathrm{~g}, 18.9$ \%, upper: $527.5 \pm 161.4 \mathrm{~g}, 12.9 \%$, middle: $505.0 \pm 91.6 \mathrm{~g}$, $12.4 \%$, base: $513.0 \pm 157.0 \mathrm{~g}, 12.6 \%$ and bottom: $604.0 \pm$ $160.0 \mathrm{~g}, 14.9 \%)$. The mean weight and percentage of total weight (\%) of each tine markedly decreased from the first tine to third tine $\left(1^{\text {st }}\right.$ tine: $454.0 \pm 171.0 \mathrm{~g}, 11.2 \%, 2^{\text {nd }}$ tine: $397.0 \pm 212.0 \mathrm{~g}, 9.8 \%$ and $3^{\text {rd }}$ tine: $\left.293.0 \pm 167.0 \mathrm{~g}, 7.2 \%\right)$. Specific gravity tended to be highest in base and bottom sections of the main beam (top: $1.07 \pm 0.07$, upper: $1.09 \pm$ 0.07 , middle: $1.13 \pm 0.08$, base: $1.16 \pm 0.08$ and bottom: 1.16 \pm 0.08 ). Specific gravity of tissue from the three tines also gradually increased from third tine to the first tine $\left(3^{\text {rd }}\right.$ tine: $1.10 \pm 0.08,2^{\text {nd }}$ tine: $1.14 \pm 0.09$ and $1^{\text {st }}$ tine: $1.17 \pm 0.08$ ). Capacity was $0.93 \mathrm{ml} / \mathrm{g}$ in the top, $0.92 \mathrm{ml} / \mathrm{g}$ in the upper, $0.89 \mathrm{ml} / \mathrm{g}$ in the middle, and $0.87 \mathrm{ml} / \mathrm{g}$ in the base and bottom sections of the main beam, and $0.87 \mathrm{ml} / \mathrm{g}$ in the first, $0.89 \mathrm{ml} / \mathrm{g}$ in the second, $0.91 \mathrm{ml} / \mathrm{g}$ in the third tine. Specific gravity of the antler was therefore negatively correlated with

Table 3. Exterior Characteristics of the Crown and Number of Tines of Antler in Elk (Cervus e. canadensis)

\begin{tabular}{lcccc}
\hline Region & Number of crowns & Depth of crown $(\mathrm{cm})$ & Girth of crown $(\mathrm{cm})$ & Number of tines \\
\hline \hline Gyeonggi-do $(n=53)$ & $2.2 \pm 0.7^{\mathrm{ab}}$ & $16.5 \pm 7.0^{\mathrm{d}}$ & $18.5 \pm 5.5^{\mathrm{c}}$ & $2.8 \pm 0.5^{\mathrm{a}}$ \\
Gangwon-do $(n=49)$ & $2.3 \pm 0.6^{\mathrm{b}}$ & $15.0 \pm 5.9^{\mathrm{cd}}$ & $16.4 \pm 4.6^{\mathrm{a}}$ & $3.0 \pm 0.7^{\mathrm{abc}}$ \\
Chungcheongbuk-do $(n=62)$ & $1.9 \pm 0.6^{\mathrm{a}}$ & $12.6 \pm 5.8^{\mathrm{ab}}$ & $16.1 \pm 3.6^{\mathrm{a}}$ & $2.9 \pm 0.4^{\mathrm{ab}}$ \\
Chungcheongnam-do $(n=68)$ & $2.1 \pm 0.6^{\mathrm{ab}}$ & $14.8 \pm 5.4^{\mathrm{c}}$ & $16.7 \pm 3.8^{\mathrm{a}}$ & $2.9 \pm 0.4^{\mathrm{abc}}$ \\
Jeollabuk-do $(n=52)$ & $2.2 \pm 0.5^{\mathrm{b}}$ & $11.6 \pm 6.8^{\mathrm{a}}$ & $16.2 \pm 4.6^{\mathrm{a}}$ & $3.1 \pm 0.5^{\mathrm{bc}}$ \\
Jeollanam-do $(n=15)$ & $2.1 \pm 0.4^{\mathrm{ab}}$ & $14.8 \pm 5.7^{\mathrm{c}}$ & $19.0 \pm 3.0^{\mathrm{c}}$ & $3.2 \pm 0.4^{\mathrm{c}}$ \\
Gyeongsangbuk-do $(n=30)$ & $2.3 \pm 0.7^{\mathrm{b}}$ & $11.9 \pm 6.2^{\mathrm{a}}$ & $17.2 \pm 4.6^{\mathrm{ab}}$ & $3.1 \pm 0.7^{\mathrm{bc}}$ \\
Gyeongsangnam-do $(n=49)$ & $2.1 \pm 0.6^{\mathrm{ab}}$ & $15.4 \pm 10.1^{\mathrm{cd}}$ & $17.5 \pm 4.4^{\mathrm{ab}}$ & $2.8 \pm 0.4^{\mathrm{a}}$ \\
Average & $2.1 \pm 0.6$ & $14.1 \pm 7.0$ & $17.2 \pm 5.5$ & $3.0 \pm 0.5$ \\
\hline
\end{tabular}

Values are means with their SD $(n=378)$.

abcd Means in each column with different superscripts differ $(\mathrm{p}<0.05)$. 
Table 4. Weight, Specific Gravity, Capacity, Diameter of Cross Section of Different Sections of Antler in Elk (Cervus e. canadensis)

\begin{tabular}{|c|c|c|c|c|c|c|c|c|c|}
\hline \multicolumn{2}{|c|}{ Item } & Top & Upper & Middle & Base & Bottom & $1^{\text {st }}$ tines & $2^{\text {nd }}$ tines & $3^{\text {rd }}$ tines \\
\hline \multicolumn{2}{|c|}{ Mean weight (g) } & $769.8 \pm 278.5$ & $527.5 \pm 161.4$ & $505.0 \pm 91.6$ & $513.0 \pm 157.0$ & $604.0 \pm 160.0$ & $454.0 \pm 171.0$ & $397.0 \pm 212.0$ & $293.0 \pm 167.0$ \\
\hline \multicolumn{2}{|c|}{$\begin{array}{l}\text { Percentage of total weight } \\
\text { (\%) }\end{array}$} & $18.9 \pm 3.8$ & $12.9 \pm 2.6$ & $12.4 \pm 2.0$ & $12.6 \pm 2.4$ & $14.9 \pm 1.8$ & $11.2 \pm 4.2$ & $9.8 \pm 3.9$ & $7.2 \pm 4.1$ \\
\hline \multicolumn{2}{|l|}{ Specific gravity } & $1.07 \pm 0.07$ & $1.09 \pm 0.07$ & $1.13 \pm 0.08$ & $1.16 \pm 0.08$ & $1.16 \pm 0.08$ & $1.17 \pm 0.08$ & $1.14 \pm 0.09$ & $1.10 \pm 0.08$ \\
\hline \multicolumn{2}{|c|}{ Capacity (ml/g) } & $0.93 \pm 0.06$ & $0.92 \pm 0.06$ & $0.89 \pm 0.06$ & $0.87 \pm 0.06$ & $0.87 \pm 0.05$ & $0.87 \pm 0.05$ & $0.89 \pm 0.06$ & $0.91 \pm 0.07$ \\
\hline \multirow{3}{*}{$\begin{array}{l}\text { Diameter of } \\
\text { cross section } \\
(\mathrm{cm})\end{array}$} & $\begin{array}{l}\text { Greatest } \\
\text { diameter }\end{array}$ & $7.5 \pm 2.4$ & $6.6 \pm 1.1$ & $6.2 \pm 1.0$ & $6.3 \pm 1.0$ & $7.6 \pm 1.3$ & $4.8 \pm 0.6$ & $5.0 \pm 1.2$ & $5.7 \pm 1.9$ \\
\hline & $\begin{array}{l}\text { Least } \\
\text { diameter }\end{array}$ & $4.9 \pm 0.4$ & $4.9 \pm 0.6$ & $5.5 \pm 0.5$ & $5.3 \pm 0.6$ & $5.5 \pm 0.5$ & $3.7 \pm 0.6$ & $3.8 \pm 0.6$ & $3.9 \pm 0.4$ \\
\hline & $\begin{array}{l}\text { Inner } \\
\text { diameter }\end{array}$ & $0.8 \pm 0.2$ & $0.9 \pm 0.2$ & $0.9 \pm 0.2$ & $0.9 \pm 0.2$ & $0.1 \pm 0.02$ & $0.8 \pm 0.2$ & $0.8 \pm 0.3$ & $1.0 \pm 0.5$ \\
\hline
\end{tabular}

Values are means with their SD $(n=18)$.

capacity. Hyvärinen et al. (1977) reported that both antler weight and antler specific gravity were related to body weight. Also, the concentrations of ash, phosphorus and magnesium in dry matter showed significant positive correlations with specific gravity (Hyvärinen et al., 1977). Antlers grow in length by endochondral ossification and in diameter by intramembranous ossification (Banks, 1974). The pattern of measurements of the greatest diameter cross section of the main beam were similar to the earlier girth measurements (top: $7.5 \pm 2.4 \mathrm{~cm}$, upper: $6.6 \pm 1.1 \mathrm{~cm}$, middle: $6.2 \pm 1.0 \mathrm{~cm}$, base: $6.3 \pm 1.0 \mathrm{~cm}$ and bottom: $7.6 \pm 1.3 \mathrm{~cm})$. In contrast, the least diameters of the cross section were similar across all regions of the main beam, and in each of the tines. However, the inner diameter of the antler was smaller in the bottom section of the main beam compared to other sections (top: $0.8 \pm 0.2 \mathrm{~cm}$, upper: $0.9 \pm 0.2 \mathrm{~cm}$, middle: $0.9 \pm$ $0.2 \mathrm{~cm}$, base: $0.9 \pm 0.2 \mathrm{~cm}$ and bottom: $0.1 \pm 0.02 \mathrm{~cm}$; $\mathrm{p}<$ 0.05). In general, it has been reported that the diameter of cross section, an indicator of mineralization, is closely related with collagen content of antler (Goss, 1983). Collagen has been suggested to be a major protein in antler (Goss, 1983). The proportion of collagen in elk antlers increases on moving down the antler, from the upper section to the base section (approximately 1.4, 2.5 and 3.2 times higher in the upper, middle and base sections, respectively, than in the tip section), with a concomitant increase in mineral content (Sunwoo et al. 1995). This is a similar pattern to our results which showed an increase in specific gravity moving down the antler. Antler growth requires a partial demineralization of the skeleton because the diet cannot supply the enormous amount of minerals required for their rapid growth (Muir et al., 1987). Recent evidence has shown that antler bone chemical composition varies both with antler region and with the size and weight (Landete-Castillejos et al., 2007). The current study provides basic information on the differentiation of physiological properties such as velvet antler production, mean length of the main beam and tines, antler girth and depth of the crown in elk across Korea. Although regional differences in the chemical composition and biological activities of velvet antler have been suggested, there is no research evaluating the physiological properties of velvet antler by region. Also, there are no criteria for quality standardization of velvet antler throughout the world. Therefore, further studies on morphological and physiochemical indicators as a quality index for velvet antler are required to differentiate domestic velvet antler from the imports.

\section{ACKNOWLEDGEMENT}

This research was supported by Technology Development Program for Agriculture and Forestry, Ministry for Food, Agriculture, Forestry and Fisheries, Republic of Korea.

\section{REFERENCES}

Ball, A. J., Thompson, J. M. and Fennessy, P. F. 1994. Relationship between velvet antler weight and liveweight in red 
deer (Cervus elaphus). N. Z. J. Agric. Res. 37:153-157.

Banks, W. J. 1974. The ossification process of the developing antler in the white-tailed deer (Odocoileus virginianus). Calcif. Tissue Res. 14:257-274.

Chapman, D. I. 1975. Antlers-bones of contention. Mamm. Rev. 5:121-172.

Elliott, J. L., Oldham, J. M., Asher, G. W., Molan, P. C. and Bass, J. J. 1996. Effect of testosterone on binding of insulinlike growth factor-I (IGF-I) and IGF-II in growing antlers of fallow deer (Dama dama). Growth Regul. 6:214-221.

Fennessy, P. F. and Suttie, J. M. 1985. Antler growth: Nutritional and endocrine factors. In: Biology of Deer Production, Fennessy, P. F. and Drew, K. R. (Eds.) New Zealand: Royal Society of New Zealand Bulletin 22. pp.239-250.

Fierro, Y., Gortázar, C., Landete Castillejos, T., Vicente, J., Garcia, A. and Gallego, L. 2002. Baseline values for cast antlers of Iberian red deer(Cervus elaphus hispanicus). Z. Jagdwiss. 48:1-8.

Gaspar López, E., José García, A., Landete Castillejos, T., Carrión, D., Estevez, J. A. and Galleg, L. 2008. Growth of the first antler in Iberian red deer (Cervus elaphus hispanicus). Eur. J. Wildl. Res. 54:1-5.

Gómez, J. A., Garcia, A., Landete-Castillejos, T. and Gallego, L. 2006. Effect of advancing births on testosterone evolution until 2.5 years of age and puberty in Iberian red deer(Cervus elaphus hispanicus). Anim. Reprod. Sci. 96:79-88.

Goss, R. J. 1983. Developmental anatomy of antlers. In: Deer Antlers: Regeneration, Function and Evolution. Goss, R. J. (Ed.) Academics Press. New York, U.S.A., pp.133-171.

Hemmings, S. and Song, X. 2004. The effects of elk velvet antler consumption on the rat: Development, behaviour, toxicity and the activity of liver gamma-glutamyltranspeptidase. Comp. Biochem. Physiol. 138:105-112.

Hyvärinen, H., Kay, R. N. and Hamilton, W. J. 1977. Variation in the weight, specific gravity and composition of the antlers of red deer (Cervus elaphus L). Br. J. Nutr. 38(3):301-311.

Ian, T., Tony, P. and Bruce, F. 2000. Elk farming handbook. pp.187-200.

Jeon, B. T., Lee, S. M., Kim, M. H. and Moon, S. H. 2005. Effects of dietary protein level on production and chemical composition of velvet antler in spotted deer (Cervus Nippon). J. Anim. Sci. \& Technol. (Kor.). 47(5):805-812.

Kierdorf, U., Schultz, M. and Fischer, K. 1993. Effects of an antiandrogen treatment on the antler cycle of male fallow deer (Dama dama L.). J. Exp. Zool. 266:195-205.

Kruuk, E. B., Slate, J., Pemberton, J. M., Brotherstone, S., Ullrey, D. E. 1983. Nutrition and antler development in white-
Guinness, F. and Clutton-Brock, T. 2002. Antler size in red deer: heritability and selection but no evolution. Evolution 56(8):1683-1695.

Landete-Castillejos, T., Garcia, A. and Gallego, L. 2001. Calf growth in captive Iberian red deer (Cervus elaphus hispanicus): effect of birth date and hind milk composition. J. Anim. Sci. 79:1085-1092.

Landete-Castillejos, T., Garcia, A. and Gallego, L. 2007. Body weight, early growth and antler size influence antler bone mineral composition of Iberian red deer(Cervus elaphus hispanicus). Bone 40:230-235.

Li, C. and Suttie, J. M. 1994. Light microscopic studies of pedicle and early first antler development in red deer (Cervus elaphus). Anat. Rec. 239:198-215.

Li, C. and Suttie, J. M. 2000. Histological studies of pedicle skin formation and its transformation to antler velvet in red deer (Cervus elaphus). Anat. Rec. 260:62-71.

Modell, W. 1969. Horns and antlers. Sci. Am. 220:114-122.

Moore, G. E., Littlejohn, R. P. and Cowie, G. M. 1988. Liveweights, growth rates and antler measurements of farmed deer stags and their usefulness as predictors of performance. N. Z. J. Agric. Res. 31:285-292.

Moreau, M., Dupuis, J., Bonneau, N. H. and Lecuyer, M. 2004. Clinical evaluation of a powder of quality elk velvet antler for the treatment of osteoarthritis in dogs. Can. Vet. J. 45:133139.

Muir, P. D. and Sykes, A. R. 1988. Effect of winter nutrition on antler development in red deer (Cervus elaphus): a field study. N. Z. J. Agric. Res. 31:145-150.

Muir, P. D., Sykes, A. R. and Barrell, G. K. 1987. Calcium metabolism in red deer(Cervus elaphus) offered herbages during antlerogenesis: kinetic and stable balance studies. J. Agric. Sci. Camb. 109:357-364.

Schmidt, K. T., Stien, A., Albon, S. D. and Guinness, F. E. 2001. Antler length of yearling red deer is determined by population density, weather and early life-history. Oecologia 127:191-197.

Sim, J. S. 1987. Uses of traditional medicines in Korea-deer antlers. In: Focus on a New Industry of the Alberta Game Grower's Association Conference. Renecker, L. A. (Ed.) pp.68-70.

Sunwoo, H. H., Nakano, T., Hudson, R. J. and Sim, J. S. 1995. Chemical composition of antlers from Wapiti (Cervus elaphus). J. Agric. Food Chem. 43:1846-1849.

Turner, C. H. and Burr, D. B. 1993. Basic biomechanical measurements of bone: a tutorial. Bone 14:595-608. 
tailed deer. In: Antler Development in Cervidae. Brown, R. D. (Ed.). Caesar Kleberg Wildlife Research Institute, Kingsville, TX, U.S.A., pp.49-59.

Ungerfeld, R., Bielli, A., Gonzalez-Pensado, S. X., Villagrán, M. and Gonzalez-Sierra, U. T. 2008. Antler size and weight in a herd of pampas deer(Ozotoceros bezoarticus). Mamm. Biol.
73(6):478-481.

Wolfe, G. J. 1982. The relationship between age and antler development in wapiti. In: Antler development in Cervidae. Brown, R. D. (Ed.). Caesar Kleberg Wildlife Research Institute, Kingsville, TX, U.S.A., pp.29-36.

(Received March 9, 2010; Revised June 7, 2010; Accepted June 8, 2010) 